\title{
Assessing the Capability of Sentinel-2A Data for Mapping Seagrass Percent Cover in Jerowaru, East Lombok
}

\author{
Muhammad A. Fauzan, Ignatius S. W. Kumara, Rifka Yogyantoro, Satrio Suwardana, \\ Nurul Fadhilah, Intansania Nurmalasari, Santi Apriyani, and Pramaditya Wicaksono
}

Received: September 2016 / Accepted: February 2017 / Published online: December 2017

() 2017 Faculty of Geography UGM and The Indonesian Geographers Association

\begin{abstract}
Remote sensing technology has been widely used in various applications related to natural resources and environment monitoring. In this paper, we evaluated the capability of new Sentinel-2A image to map the distribution and percent cover of seagrass in optically shallow water of Jerowaru coastal area, East Lombok. Seagrass distribution map was produced from radiometrically and geometrically corrected Sentinel-2A image with overall accuracy of $61.9 \%$. Using empirical model, seagrass percent cover was predicted with maximum coefficient of determination (R2) of 0.51 and standard error of estimate (SE) of 19.4\%. The results suggest that Sentinel-2A image can be used to perform seagrass mapping time and cost-effectively and can be further improved by incorporating more robust empirical modeling technique.
\end{abstract}

Key words: Remote sensing, Sentinel-2A, Seagrass, Mapping

\begin{abstract}
Abstrak Teknologi penginderaan jauh telah banyak digunakan dalam berbagai aplikasi terkait inventarisasi sumberdaya alam dan pemantauan lingkungan. Pada penelitian ini, kemampuan data penginderaan jauh Sentinel-2A diuji untuk memetakan distribusi dan persentase tutupan padang lamun di perairan laut dangkal Kecamatan Jerowaru, Lombok Timur. Peta distribusi padang lamun dihasilkan dari citra Sentinel-2A terkoreksi radiometrik dan geometrik dengan akurasi 61,9\%. Menggunakan model empiris, persentase tutupan lamun diestimasi dari citra Sentinel-2A dengan koefisien determinasi $\left(R^{2}\right)$ sebesar 0,51 dan standard error (SE) sebesar 19,4\%. Hasil penelitian ini menunjukkan data penginderaan jauh Sentinel-2A dapat digunakan untuk dalam pemetaan padang lamun dengan waktu dan biaya yang efektif.
\end{abstract}

Kata kunci: Penginderaan jauh, Sentinel-2A, Padang lamun, Pemetaan

\section{Introduction}

The coastal zone is essential to marine life and support a large part of the world's living marine resources [Short \& Coles, 2001]. One of the most valuable resources in the coastal area is seagrass. Seagrass habitats provide various ecological services such as fish feeding and nursery grounds, sediment stabilizer, and carbon storage [Hogarth, 2015]. Despite its importance, seagrass habitats are exposed to pressure and threat from anthropogenic and natural impact [Nadiarti, et al., 2012]. A study found that Indonesia has lost 30\% area of its seagrass beds [UNEP, 2004].

In order to reverse the degradation trends, there is a growing need to map and monitor distribution and abundance of seagrass beds. This may provide useful

Muhammad A. Fauzan, Ignatius S. W. Kumara, Rifka Yogyantoro, Satrio Suwardana, Nurul Fadhilah, Intansania Nurmalasari, Santi Apriyani, and Pramaditya Wicaksono

Cartography \& Remote Sensing, Department of Geographic Information Science,

Faculty of Geography, Universitas Gadjah Mada, Yogyakarta, Indonesia.

Correspondent email: m.afif.fauzan@mail.ugm.ac.id information for management and conservation strategy in coastal area. For decades, remote sensing technology has been widely used for mapping and monitoring coastal and shallow sea environment because of its cost-effectiveness and large area coverage [Hartono, 1994; Mumby, et al., 1997]. Several studies succesfully used remote sensing data to map seagrass area and percentage cover [Pu, et al., 2012], species composition [Fyfe, 2003], and other biophysical properties such as leaf area index [Wicaksono \& Hafizt, 2013], biomass [Knudby \& Nordlund 2011], and above-ground carbon stock [Wicaksono, 2015].

The capability of moderate spatial resolution remote sensing data such as Landsat (30 m pixel size) and ASTER-VNIR (15 m pixel size) has already been demonstrated for mapping and monitoring seagrass biophysical characteristics [Armstrong, 1993; Mumby, et al., 1997; Wicaksono \& Hafizt, 2013; Pu, et al., 2014]. Those data are available for free, and has high revisit capability, and thus very useful to map large area cost effectively. Recently, a new earth-observation satellite named Sentinel-2A was launched on June 2015 as part of Sentinels mission and Europe's Copernicus programme to provide data continuity for environmental 
monitoring of earth surface. Sentinel-2A satellite carries mult-ispectral imager (MSI) onboard with 13 spectral bands at visible, near-infrared, and shortwave-infrared wavelength with 10,20 , and $60 \mathrm{~m}$ spatial resolution, respectively. Moreover, the multispectral imager is capable of covering wide swath of $290 \mathrm{~km}$, has frequent revisit time, and can be obtained freely, which make it very potential to be used in wide range of applications [ESA, 2015]. However, mapping seagrass abundance has never been done using Sentinel-2A data. This study aims to evaluate the performance of Sentinel-2A image to understand its potentials and usefulness for mapping seagrass biophysical properties. Seagrass percent cover was selected as the parameter of interest to be mapped, since it is currently recognized as a key parameter for seagrass monitoring effort [McKenzie, et al., 2001]. Seagrass percent cover is defined as the area of substrate which is covered by seagrass when observed directly from above [Phinn, et al.. 2008].

\section{The Methods}

\section{Study area}

This research was carried out in part of north coastal area of Jerowaru District, East Lombok Region, Nusa Tenggara Barat Province. Seagrass are located in optically shallow water ( $<3 \mathrm{~m}$ depth) on sand and mud substrate and dominated by species such as Enhalus acoroides, Thalassia hemprichii, and Cymodocea rotundata. Several less-dominant species such as Halophila ovalis and Halodule universis are also present. The condition of seagrass beds vary from continous beds with single species and mixed species to patchy beds. Seagrass beds in this study area are associated with other benthic organisms such as micro benthos and coral reefs.

\section{Field methods}

Fieldwork was carried out from 22 - 25 May 2016. Prior to field survey, visual and digital image interpretation was performed to determine field data location. Point-based field data of substrate type, seagrass species composition, and percent cover were collected with photo-quadrat and photo-transect method [Roelfsema, et al. 2014] by snorkeller using digital underwater camera and $1 \mathrm{~m}^{2}$ quadrat. A handheld global positioning system device (GPS) was towed to a snorkeller to acquire field data position. Photos taken from field survey were interpreted in the laboratory.

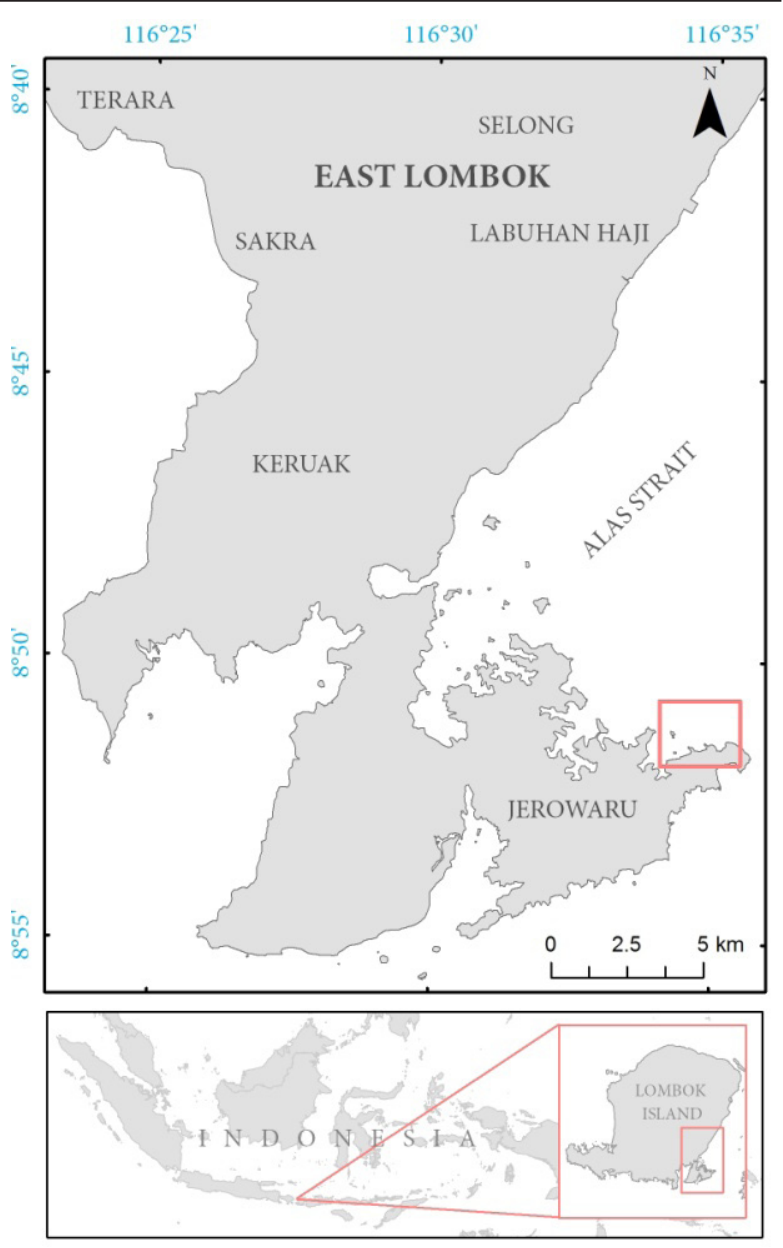

Figure 1 . The location of study area

A total of 253 data points were collected and generalized into 96 samples to match Sentinel-2A image pixel size, which are presented in Figure 2. From all these samples, 80 samples are seagrass, and 16 others are non-seagrass. Half of seagrass samples were used to train the maximum likelihood classification algorithm and develop the empirical model, while the other half was used for accuracy assessment.

\section{Image data and pre-processing}

Remote sensing data used in this study is Sentinel-2A Level-1C (top-of-atmosphere reflectance) image, covering Jerowaru District, and acquired on 18 May 2016 from Sentinels Scientific Data Hub (http://scihub.copernicus. $\underline{\mathrm{eu}})$. Only visible spectral bands with $10 \mathrm{~m}$ pixel size (band 2, band 3, band 4) were used in this study. These bands were selected because of their capability of penetrating water body, so that the features on the optically shallow water can be detected by the imaging sensor [Green, et al., 2000]. Atmospheric correction was applied to the data using dark object substraction method [Chavez, et al., 1977] performed. Water column 
effect was compensated using method developed by Lyzenga [1981], producing single depthinvariant bottom index from each pair of spectral bands. In this study, we named these depthinvariant bottom index (DII) bands as b2b3, $\mathrm{b} 2 \mathrm{~b} 4$, and $\mathrm{b} 3 \mathrm{~b} 4$, representing the pair of the origin spectral bands being used. These three DII bands no longer contains reflectance information of seabed objects but the normalized index value invariant to the variation of depth.

\section{Benthic habitat mapping}

Digital supervised image classification with Maximum Likelihood algorithm was applied on three DII from Sentinel-2A image to produce benthic habitat map. This habitat map was used to distinguish seagrass and non-seagrass area, since only seagrass pixels were used to map seagrass percent cover. Since seagrass biophysical properties were controlled by species [Wicaksono, 2015], it was necessary to differentiate seagrass based on its morphology or canopy structure [Wicaksono \& Hafizt, 2013]. The classification scheme used consists of six classes, which are bare substrate, coral reefs, Ea-seagrass, EaTh- seagrass, $T h C r$-seagrass, and optically deep water. Details of seagrass classes are presented on Table 1. Confusion matrix analysis [Congalton, 1991] were used to assess the classification accuracy of benthic habitats map.

\section{Seagrass percent cover mapping}

Empirical modelling approach was performed to estimate seagrass percent cover by calibrating DII values with corresponding field seagrass percent cover data. We developed four linear regression models, three models for each class of seagrass $(E a, T h C r, E a T h)$ and one model for all class of seagrass regardless of their species and canopy structure. Seagrass percent cover data were used as the dependent variable while DII values were as the independent variable. From three DII bands, only bands that produced significant correlation at $95 \%$ confidence level $(95 \% \mathrm{CL})$ with field data were used as input in the empirical modeling of seagrass percent cover using regression analysis. The accuracy of the estimated seagrass percent cover was calculated using standard error of estimate (SE).

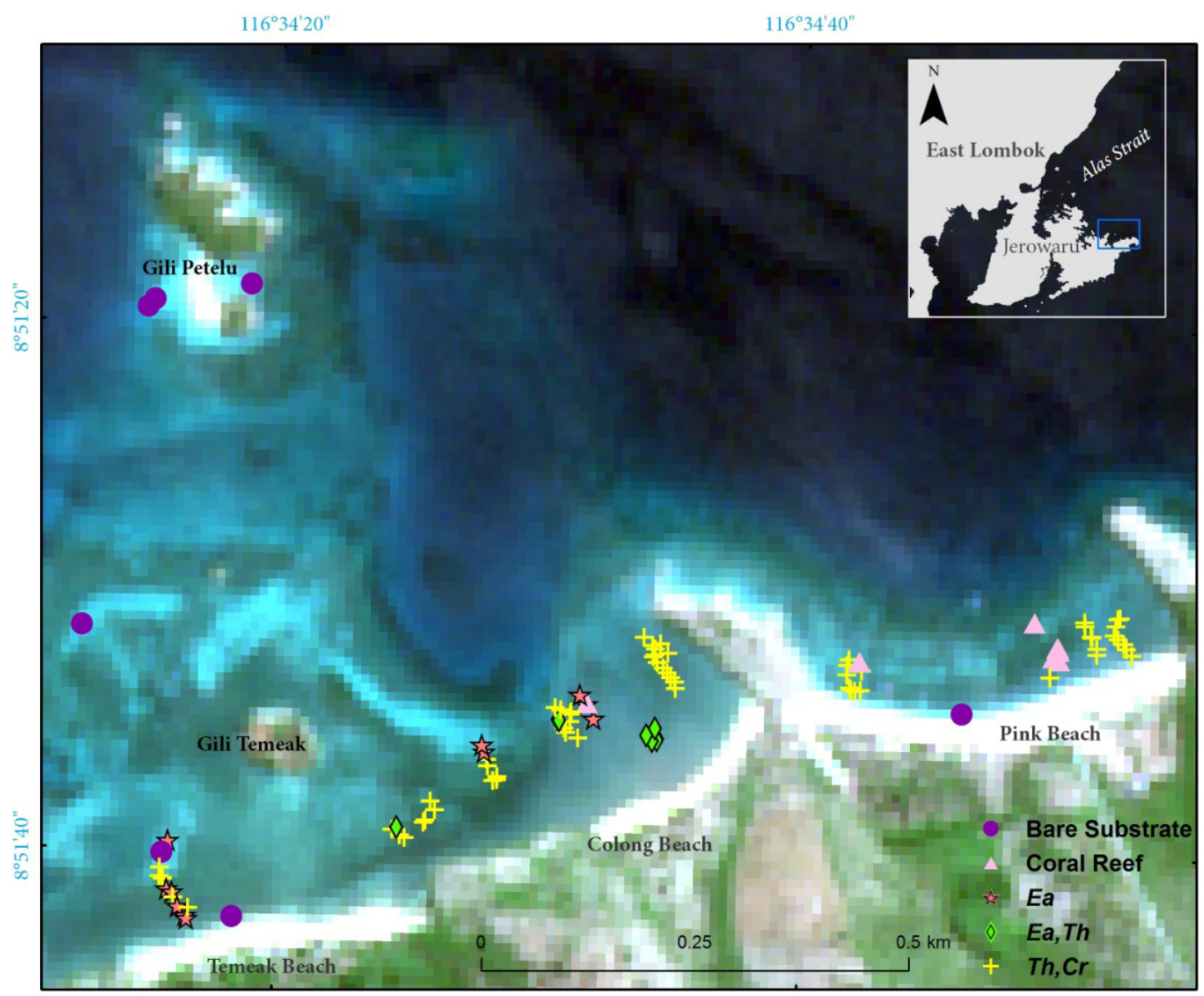

Figure 2. Field data distribution at study area 
Table 1. Seagrass classification scheme based on morphology or canopy structure

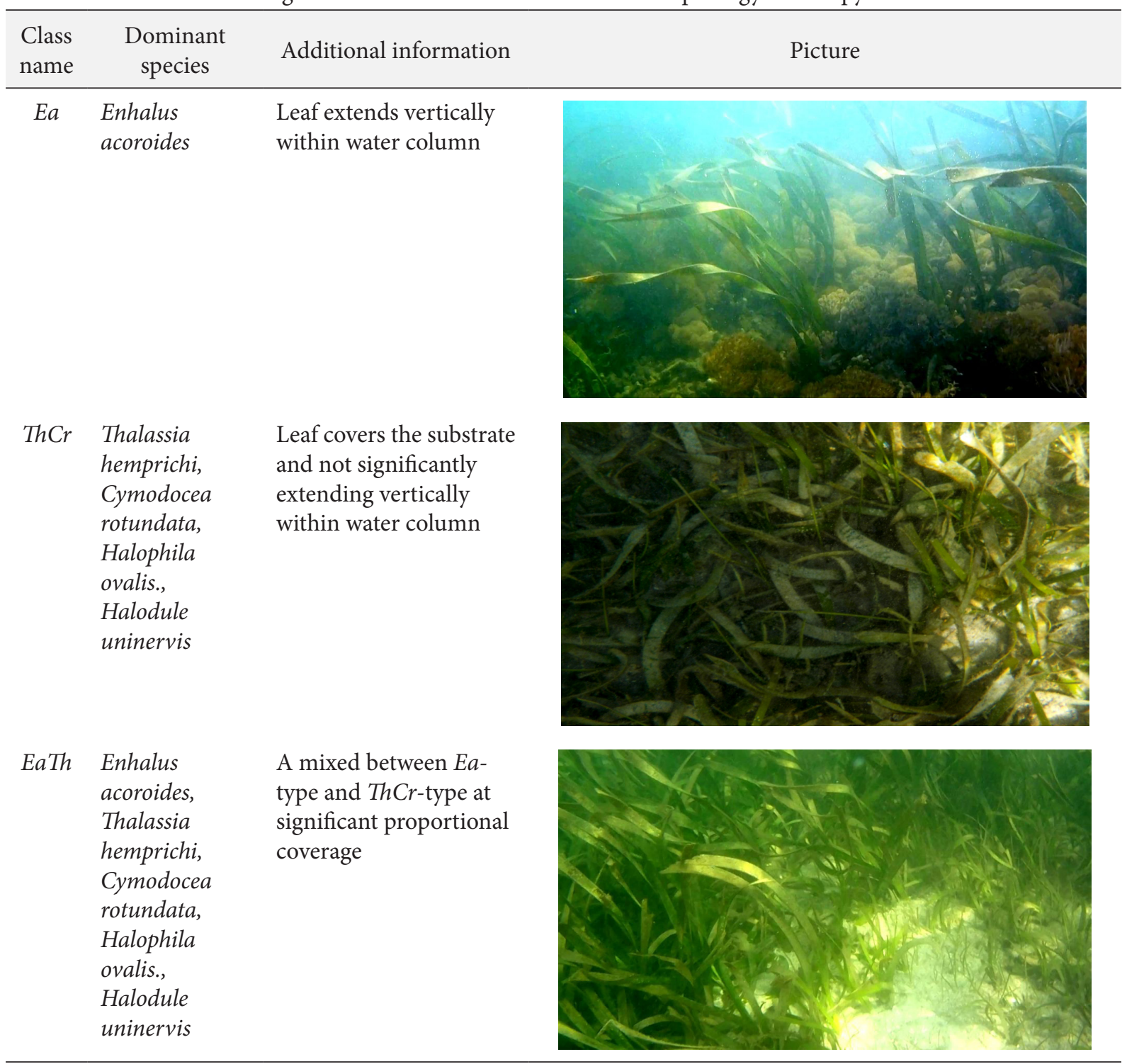

Source: Wicaksono \& Hafizt [2013]

\section{Result and Discussion}

\section{Mapping seagrass distribution}

The result of Maximum Likelihood classification is shown in Figure 3. An overall accuracy of $61.9 \%$ was obtained. The class with the lowest user and producer accuracy is $E a$, where the user accuracy is zero percent $(0 \%)$, which mean that there is no chance that the $E a$ class in the classified image is actually seagrass in the field. In addition, $0 \%$ of $E a$ class producer accuracy also means that no Ea class in the field is correctly classified. EaTh class, which contains Ea species, was also tend to be missclassified as $\mathrm{ThCr}$ class. Both bare substratum and coral reef class also suffered from similar misclassification, where most of them were classified as ThCr. Optically deep water is the only class that was classified correctly, suggesting that it was spectrally distinct compared to benthic habitats in optically shallow water.

These errors may come from various factors. The first factor could be the environmental conditions of our study site. Our study site is a complex environment, where multiple species of seagrass and other benthic covers such as coral reefs and macro algae are present. During the high tide, the wave is likely causing a turbulance, which increases the water turbidity, due to the presence of limestone cliffs which separates one beach to another. The suspension caused by wave turbulance may affect the reflectance from water column and limit the penetration capability of Sentinel-2A visible bands.

The second factor is the spatial resolution of Sentinel-2A image. At $100 \mathrm{~m}^{2}$, reflectances from objects in the corresponding pixel were 
generalized. In addition, it is also problematic when different benthic objects are located adjacent to each other. The bandwidth and wavelength sensitivity of Sentinel-2A spectral bands may also incapable of detecting the difference of unique reflectance from each seagrass class. Previous study shows that at less complex environment with homogenous benthic type, multispectral data have better performance in mapping benthic habitats [Green, et al., 2000; Goodman, et al., 2013].

Third, these high misclassification rates of seagrass classes are mainly due to the limitation of samples available. Given more samples, we may yield better results as in Wicaksono \& Hafizt [2013]. The last factor, even though the probability is small, the error may be caused by the misidentification and inconsistencies of interpreter in interpreting the field photos, suggesting that mapping benthic habitats as well as seagrass species composition in complex environment using remote sensing is still a difficult task.

\section{Mapping seagrass percent cover}

The empirical modeling of seagrass percent cover using Sentinel-2A image was performed using linear regression analysis. Linear regression models between Depth-invariant bottom index (DII) and field seagrass percent cover data produced high coefficient of determination $\left(R^{2}\right)$. Linear regression graphics of the strongest relationship between DII and field seagrass percent cover for each seagrass class are presented in Figure 4. The accuracy of the estimated seagrass percent cover was provided at Table 3.

Table 2. Confusion matrix for classification of nearshore benthic habitats at the study area. Field data in columns, classification results in rows

\begin{tabular}{lcccccccc}
\hline & Ea & EaTh & ThCr & $\begin{array}{c}\text { Bare } \\
\text { substrate }\end{array}$ & Coral reef & $\begin{array}{c}\text { Optically } \\
\text { Deep water }\end{array}$ & Total & $\begin{array}{c}\text { User accuracy } \\
(\%)\end{array}$ \\
\hline Ea & $\mathbf{0}$ & 1 & 8 & 0 & 0 & 0 & 9 & 0.0 \\
EaTh & 0 & $\mathbf{1}$ & 3 & 0 & 0 & 0 & 4 & 25.0 \\
ThCr & 1 & 0 & $\mathbf{8}$ & 0 & 1 & 0 & 10 & 80.0 \\
Bare substrate & 1 & 0 & 1 & $\mathbf{2}$ & 0 & 0 & 4 & 50.0 \\
Coral reef & 3 & 0 & 8 & 0 & $\mathbf{2}$ & 0 & 13 & 15.4 \\
Optically Deep water & 0 & 0 & 0 & 0 & 0 & $\mathbf{3 1}$ & 31 & 100.0 \\
Total & 5 & 2 & 28 & 2 & 3 & 31 & $\mathbf{7 1}$ & Overall accuracy \\
Producer accuracy (\%) & 0.0 & 50.0 & 28.6 & 100.0 & 67.0 & 100.0 & & $=61.9$ \\
\hline
\end{tabular}

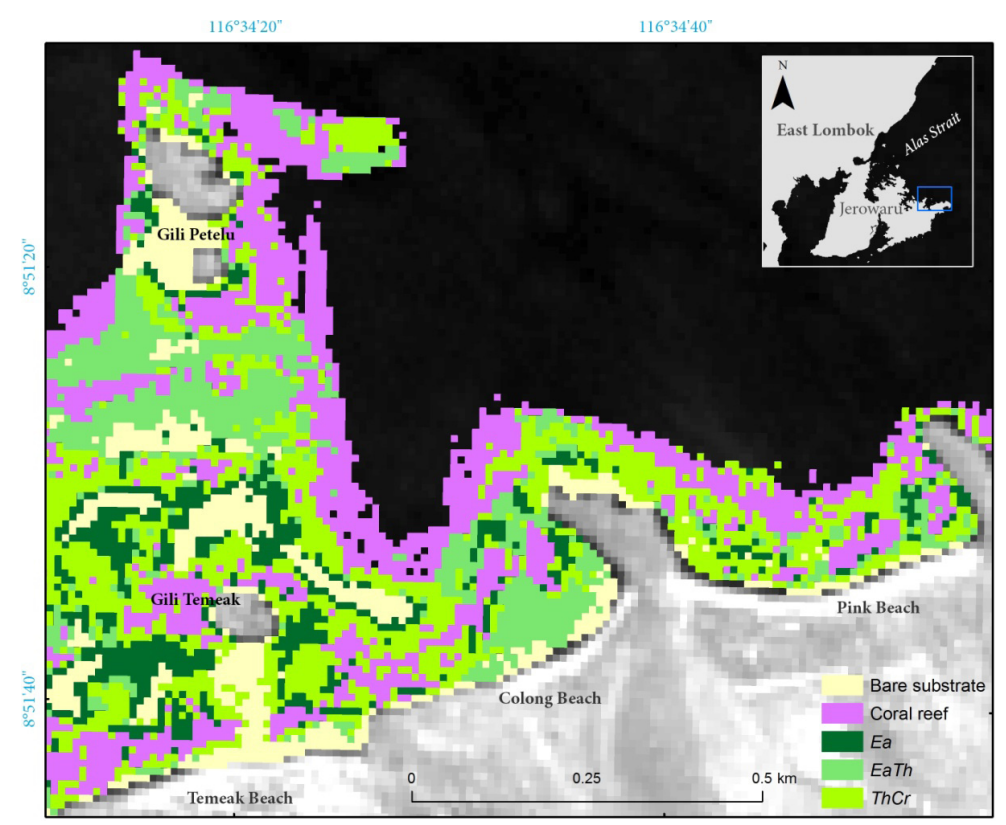

Figure 3. The result of Maximum Likelihood classification with $61.9 \%$ overall accuracy 
The resultant regression function obtained from these empirical models can only be applied on the corresponding seagrass pixels. Thus, we have four different seagrass percent cover models based on the empirical model of each seagrass class. Table 3 shows the SE of the estimated seagrass percent cover from the model. Because the habitat map produced from multispectral classification was not capable to distinguish seagrass with different type of canopy structure, it was not possible to map seagrass percent cover for each seagrass type separately using these three empirical models. Hence, the only model used to map seagrass percent cover is the model developed from DII b2b4 for all seagrass class. In this complex environment where the water is slightly turbid and multiple seagrass species and associate benthic habitats are present, empirical model created from DII b2b4 derived from Sentinel-2A image had $R^{2}$ of 0.51 with SE of $19.4 \%$.

The accuracy of seagrass mapping of this research is lower than the result obtained by Topouzelis et al. [2016]. Nevertheless, the accuracy of seagrass percent cover model obtained in this research is not comparable to the research conducted by Topouzelis, et al. [2016] although they used similar sensor, especially since their class complexity is lower than in our research. Their classification scheme consists of seagrass, soft bottom and hard bottom, while in this research we mapped the species composition.
Table 3. Accuracy assessment for seagrass percent cover model

\begin{tabular}{lll}
\hline Validation sample & Band & $\begin{array}{l}\text { SE } \\
(\%)\end{array}$ \\
\hline$E a(\mathrm{n}=5)$ & DII b2b4 & 37.8 \\
$\operatorname{ThCr}(\mathrm{n}=28)$ & DII b2b4 & 18.0 \\
$E a T h(\mathrm{n}=3)$ & DII b3b4 & 63.8 \\
Total seagrass $(\mathrm{n}=36)$ & DII b2b4 & 19.4 \\
\hline
\end{tabular}

Separating seagrass from other benthic habitats is more feasible than differentiating various seagrass species. However, our accuracy is comparable to other several studies that utilized different sensors. Using hyperspectral EO-1 Hyperion data with $30 \mathrm{~m}$ spatial resolution, $\mathrm{Pu}$, et al. [2012] achieved $R^{2}$ of 0.78 and SE of $15.7 \%$ at shallow clear water Northwest coastline of Florida. Landsat $5 \mathrm{TM}$ data produced lower result with $R^{2}$ of 0.59 and SE of $21.2 \%$.

When mapping seagrass percent cover, Phinn, et al. [2008] suggested a classification method with several classes of percent cover range in case the correlation between spectral band reflectance and seagrass percent cover is not significant to enable the development of percent cover estimation based on regression analysis. At the same spatial resolution as Sentinel-2 data, SPOT-5 data managed to map monobed Posidonia oceanica seagrass at Laganas Bay, Greece with four

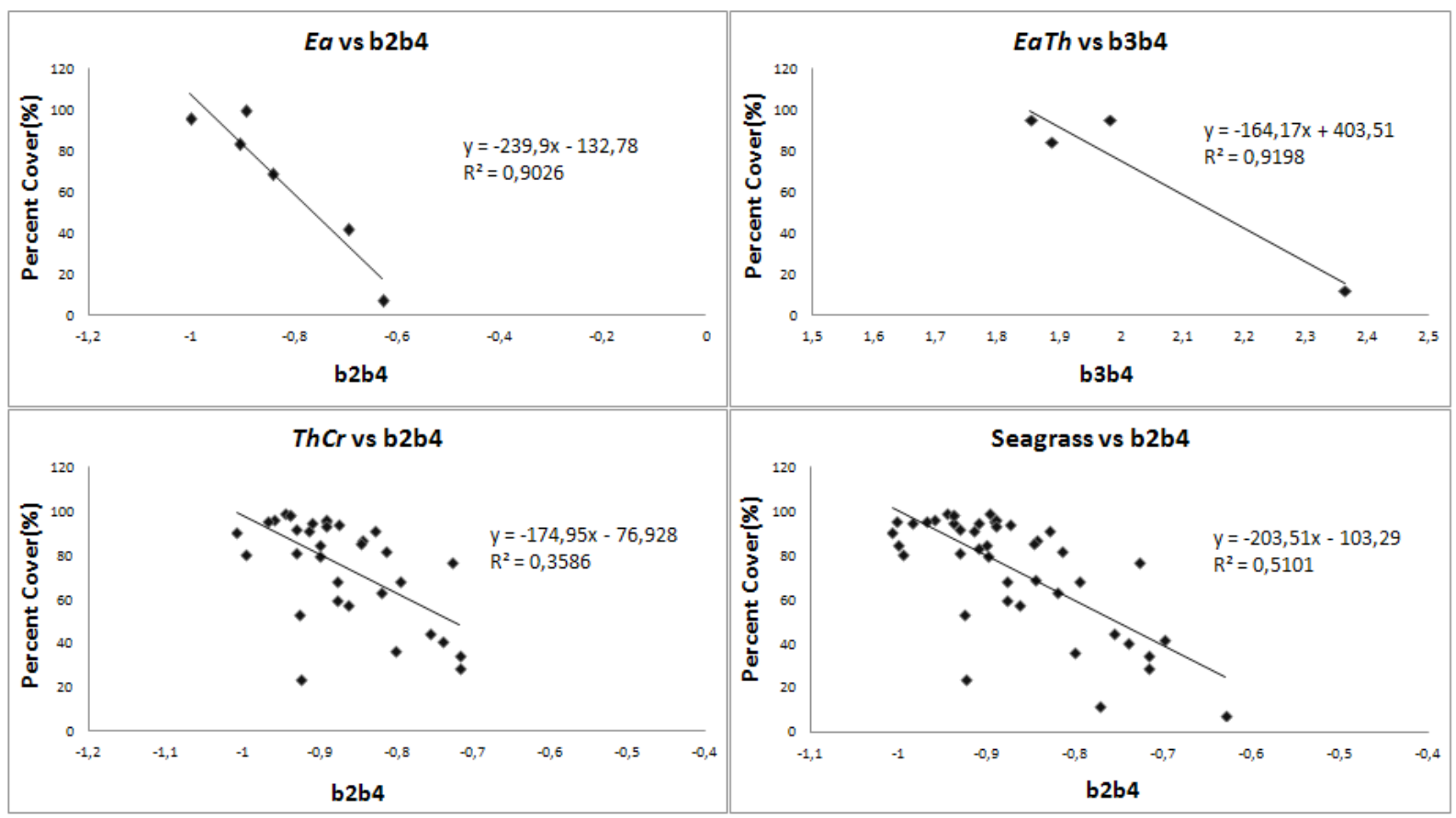

Figure 4. Linear regression analysis between DII value and field seagrass percent cover showing mild (b2b4 $T h C r$ ) to strong (b2b4 - Ea, b3b4 - EaTh, b2b4 - all classes) prediction power 
benthic classes including dense cover seagrass, sparse cover seagrass, algae, and sand with high classification accuracy of $96 \%$ [Pasquialini, et al., 2005]. This research also revealed that increasing the spatial resolution does not always have a positive impact in the accuracy of classification. In fact, pan-sharpened SPOT-5 image with $2.5 \mathrm{~m}$ spatial resolution at the same region and classification scheme produced lower classification accuracy of $73 \%$ [Pasquialini, et al., 2005]. Phinn, et al. [2008] used Landsat 5 TM, CASI, and Quickbird image with spatial resolution of $30 \mathrm{~m}, 4 \mathrm{~m}$, and $2.4 \mathrm{~m}$ respectively, to map four categories of seagrass percent cover at multi-species seagrass bed of Moreton Bay, and resulted in classification accuracy not larger than $45 \%$, suggessting the ineffectiveness of these images in distingusishing seagrass percent cover class using digital classification.

Most of seagrass percent cover mapping approach used digital classification and resulting in classes of seagrass percent cover range, or simpler class such as dense or sparse class of seagrass. However, mapping seagrass percent cover with empirical model results in more precise information since every pixel will have its own percent cover value. This model later can be used as the baseline for deriving another seagrass biophysical properties such as standing crop or above-ground biomass and leaf-area index, which are the properties that highly correlated with seagrass percent cover [Wicaksono, 2015]. The resulting seagrass percent cover map is presented in Figure 5.

\section{Conclusion}

North coastal area of Jerowaru District is a complex environment, with the presence of several species of seagrass and associate benthic habitats. We found that even in the complex environment such as our study area, Sentinel-2A image can be used to map seagrass habitat distribution up to $61.9 \%$ overall accuracy and seagrass percent cover with SE of $19.4 \%$. The accuracy could be better given more samples used to train and calibrate the image. Applying additional spectral transformations such as Principle Component Analysis (PCA) or Independent Component Analysis (ICA) [Wicaksono, 2016] might increase the accuracy and robustness of empirical modelling result. Hence,

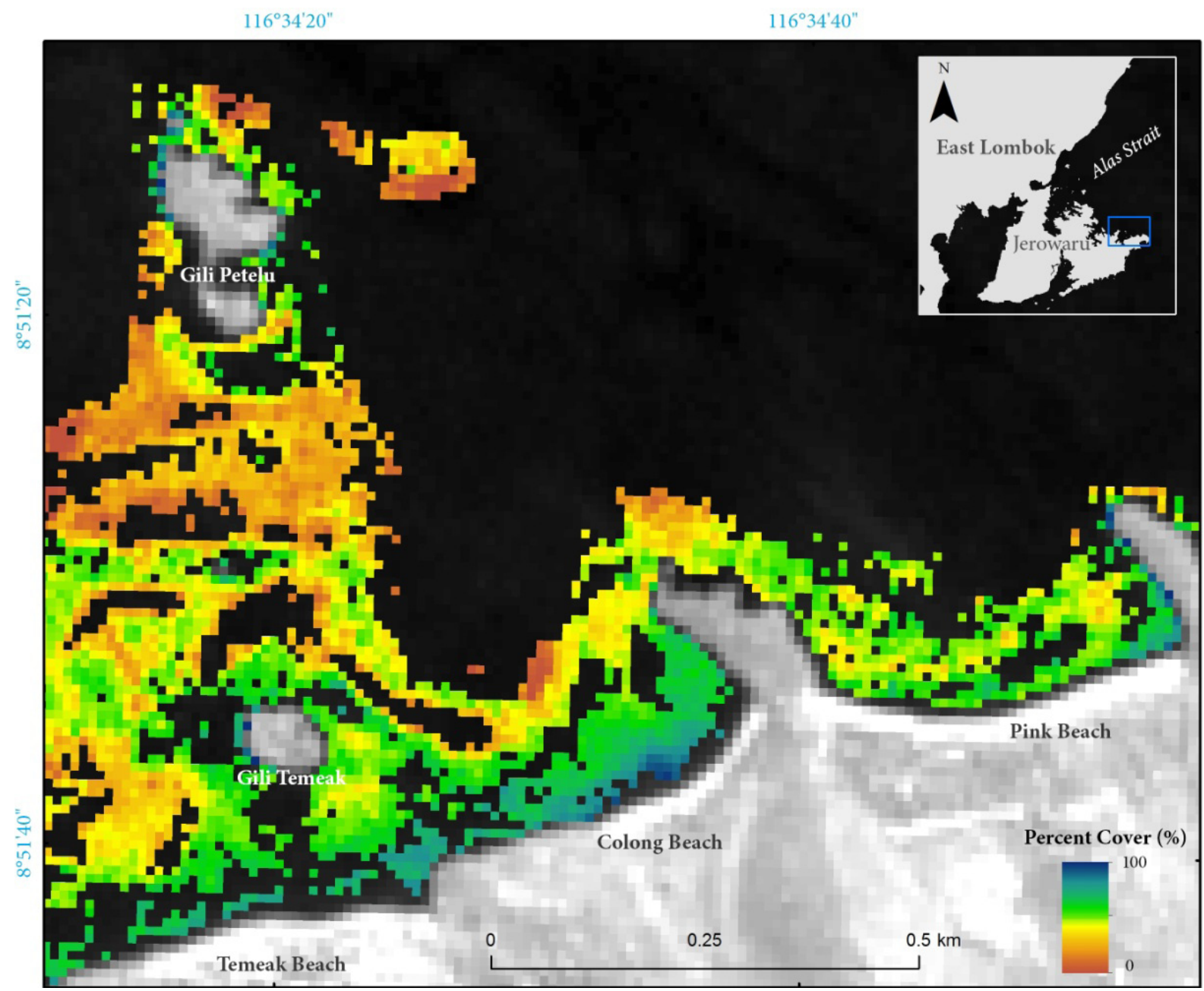

Figure 5. Seagrass percent cover map modeled from DII b2b4 with SE 19.4\% 
we concluded that Sentinel-2A could be a good data source for mapping and monitoring resources in coastal and nearshore optically shallow water environment over large area overtime cost-effectively.

\section{Acknowledgement}

Indetification of seagrass species from field photos was partially assisted by KSK Biogama (Faculty of Biology, Universitas Gadjah Mada). Land and water transportations during fieldwork was provided by Pak Hisyam and Pak Laodang. Finally, authors wish to thank Dr. Wirastuti Widyatmanti for valuable inputs during the study.

\section{References}

Armstrong, R. A. (1993). Remote sensing of submerged vegetation canopies for biomass estimation. International Journal of Remote Sensing, 14(3), 621-627.

Chavez, P., Berlin, G., \& Mitchell, W. (1977). Computer Enhancement Techniques of Landsat MSS Digital Images for Landuse/Landcover Assessments. Remote Sensing of Earth Resources, 6, 259.

Congalton, R. G. (1991). A review of assessing the accuracy of classifications of remotely sensed data. Remote Sensing of Environment, 37(1), 35-46.

[ESA] European Space Agency. (2015). ESA Bulletin 161(1).

Fyfe, S. K. (2003). Spatial and temporal variation in spectral reflectance: are seagrass species spectrally distinct? Limnology and Oceanography, 48, 464479.

Green E. P., Mumby P. J., Edwards, A. J., Clark, C. D. (2000). Remote Sensing Handbook for Tropical Coastal Management. Coastal Management Sourcebooks 3, UNESCO, Paris.

Goodman, J. A., Purkis, S. J., \& Phinn, S. R. (2013). Coral Reef Remote Sensing A Guide for Mapping, Monitoring and Management. (S. R. Phinn, Ed.) Springer.

Hartono. (1994). The use of SPOT image for mangrove inventory in Cimanuk Delta, West Java, Indonesia. Indonesian Journal of Geography, 26(28), 11-26.

Hogarth, P. J. (2015). The Biology of Mangroves and Seagrasses. Oxford: Oxford University Press.

Knubdy, A., Nordlund, L. (2011). Remote Sensing of seagrasses in a patchy multi-species environment. International Journal of Remote Sensing, 32(8), 2227-2244.

Lyzenga, D. R. (1981). Remote sensing of bottom reflectance and water attenuation parameters in shallow water using aircraft and Landsat data. International Journal of Remote Sensing, 71-82.
McKenzie, L., Finkbeiner, M. A., \& Kirkman, H. (2001). Seagrass Mapping Methods. Global Seagrass Research Methods. F. T. Short \& R .G. Coles. Amsterdam: Elsevier, 101-122.

Mumby, P. J., Green, EP., Edwards, AJ., Clark, CD. (1997). Measurement of seagrass standing crop using satellite and digital airborne remote sensing. Marine Ecology Progress Series, 159, 51-60.

Nadiarti, Riani, E., Ita D., Sugeng, B., Ari, P., Harald, A. (2012). Challenging for seagrass management in Indonesia. Journal of Coastal Development, 15(3), 234-242.

Pasqualini, V., Pergent-Martini, C., Pergent, G., Agreil, M., Skoufas, G., Sourbes, L., Tsirika, A. (2005). Use of SPOT 5 for mapping seagrasses: An application to Posidonia oceanica. Remote Sensing of Environment, 94, 39-45.

Phinn, S., Roelfsema, C., Dekker, A., Brando. V., Anstee, J. (2008). Mapping seagrass species, cover and biomass in shallow waters: An assessment of satellite multi-spectral and airborne hyperspectral imaging systems in Moreton Bay (Australia). Remote Sensing of Environment, 112, 3413-3425.

Pu, R., Bell, S. S, Meyer, C. A., Baggert, L. P, Zhao, Y. (2012). Mapping and assessing seagrass along the western coast of Florida using Landsat TM and EO-1 ALI/Hyperion imagery. Estuarine, Coastal, and Shelf Science, 115, 234-245.

Pu, R., Bell, S. S., Meyer, C. A. (2014). Mapping and assessing seagrass bed changes in Central Florida's west coast using multitemporal Landsat TM imagery. Estuarine, Coastal, and Shelf Science, 149, 68-79.

Roelfsema, C., Kovacs, E.M., Phinn, S. (2014). Field data sets for seagrass biophysical properties for the Eastern Banks, Moreton Bay, Australia, 20042014. Scientific Data.

Short, F.T., Coles, R.G. (2001). Global Seagrass Research Methods. Amsterdam: Elsevier.

Topouzelis, K., Spondylidis, S. C., Papakonstantinou, A., Soulakellis, N. (2016). The use of Sentinel-2 imagery for seagrass mapping: Kalloni Gulf (Lesvos Island, Greece) case study. Proceedings of SPIE 9688, Fourth International Conference of Remote Sensing and Geoinformation of the Environment.

[UNEP] United Nations Environment Programme. (2004). Seagrass in the South China sea. UNEP Technical Publication, 3. Bangkok.

Wicaksono, P., Hafizt, M. (2013). Mapping seagrass from space: addressing of complexity of LAI seagrass mapping. European Journal of Remote Sensing, 46, 18-39. 
Wicaksono, P. (2015). Remote Sensing Model Development for Seagrass and Mangrove Carbon Stock Mapping. Dissertation. Yogyakarta: Faculty of Geography, Universitas Gadjah Mada.

Wicaksono, P. (2016). Improving the accuracy of multispectral-based benthic habitats mapping using image rotations: the application of principle component analysis and independent component analysis. European Journal of Remote Sensing, 49: 433-463. 